\title{
Final Harvest and Pooling of Viral Vectors
}

National Cancer Institute

\section{Source}

National Cancer Institute. Final Harvest and Pooling of Viral Vectors. NCI Thesaurus.

Code C113014.

Procedures for extraction and collection of viral vectors from cultured cells. 